Alla Molchanova,

Candidate of Sciences, Institute of perspective directions and technologies, Russian State Social University (Moscow, Russian Federation);

Natalya Chunikhina,

Candidate of Sciences, Department of Business Informatics and Mathematics, Tyumen Industrial University (Tyumen, Russian Federation);

Wadim Strielkowski,

PhD, Centre for Scientometrics Research, Professor, Prague Business School (Prague, Czech Republic); Visiting Scholar, University of California, Berkeley (Berkeley, USA)

\title{
INNOVATIONS AND ACADEMIC PUBLISHING: WHO WILL CAST THE FIRST STONE?
}

Academic publishing has always been open to innovations of various kinds. Publications in prestigious academic journals have a significant impact on the institutional rankings and funding. Most recently, the question "where" to publish became more important than "what" to publish. However, the existing system is often abused by many academics.

Czech Republic is one of the countries that seem to be particularly obsessed with the issue of "predatory" journals, which led to numerous accusations and even paid mass media involvement. Yet, everyone in the Czech Republic (including the top officials of the country's leading universities as well as the Czech Academy of Sciences) has been or is publishing papers in the journals that were once considered "predatory" according to "Beall's List" (for example journals published by MDPI or Hindawi). A plethora of Czech academic got their promotions based on publishing their monographs in obscure Czech publishing houses located in apartment blocks and listing non-existing people on their scientific boards, or publishing their numerous papers in the journals are editors of without any peer review (a famous "Stöckelová controversy").

Between 2009 and 2013, Czech universities made approximately \$2 million on payments from government funding as rewards for papers and monographs published in "predatory" publishing outlets. Yet, the case of "predatory" journals has been used by some mediocre Czech (social) scientists to question the system of world's established academic metrics represented by Scopus and Web of Science. However, the creation of local publication standards would enable small groups of academics to control job promotions within the research instructions and universities and influence the division of state funding envisaged for supporting research and innovations. International academic databases, such as Scopus and Web of Science, ensure the transparency and objectivity and thence represent the best way of measuring the scientific output and productivity.

Keywords: innovations, academic publishing, predatory journals, Stöckelová controversy, Durnová controversy, peer review, Scopus, Web of Science.

DOI: 10.21272/mmi.2017.4-03

Introduction. Academic publishing represents a very profitable business. Publishing companies are very innovative in making profits by letting scientists to publish their papers in scientific journals. Once the papers are published, the access to these papers is sold back to the same scientists in the form of subscriptions to academic databases and library fees [1].

In every country and in every academic community, there are always contradicting views and opinions with regard to academic publishing. Some researchers think that science cannot be bought and sold while the others want to commercialize it. One way or the other, it is obvious that the pressure on academics is getting higher with each year and the competition is getting harder. As a result, a decision "where" to publish becomes more important than "what" to publish for many researchers [2].

In spite of all innovations in academic publishing, one would probably agree that the main principle should be that the rules of the publishing game cannot be changed during the game. Ones the rules for the academic 
publishing are set, it is unethical to try to reshape them. Yet, this is what happens quite often.

The most notorious and alarming example of how the rules of the game can be changed during the game is the "predatory journals" debacle that took place in the Czech Republic in 2015. Since then, the Czech researchers and academics are wasting their precious time on pointless debates and mutual accusations of "predatory" publishing. In fact, this trend can be also observed in other Central and Eastern European countries [3].

The term "predatory" journals was invented by Jeffrey Beall, a librarian from the University of Colorado Denver [4]. Although Jeffrey Beall is considered to be an academic expert in questionable publishing practices by many scientists, his "list of potential, possible, or probable predatory scholarly open-access journals" was merely his private blog and it was never backed up by any official institutions nor was it recognized by the authorities in most of the countries in the world. In January 2017, Beall decided to delete his blog and went into hiding. The "Beall's List" does not exist anymore but (speaking in the words of Karl Marx) its spectre is still haunting Europe (and the rest of the world).

Czech Republic is a clear example of this. In 2013, the Research, Development and Innovation Council of the Czech government set very clear criteria for judging the academic value of all publications which was based on whether the journal in question was listed in Scopus or Web of Science (WoS) databases. Unfortunately, many researchers doubt these governmental standards and are searching for "predatory journals among the journals indexed by Scopus and Web of Science. The comical but also a very sad thing is that the majority of these "predatory" journal "hunters" publish or published in "predatory" journals (listed in Scopus or WoS) themselves. Among the most notorious supporters of double standards are the top management representatives of the Czech Academy of Sciences or the Charles University in Prague [5]. Speaking in the words from the Bible: "Who would be the first to cast the stone?".

The main objective of this paper is to focus on the issue of innovations in academic publishing. We are analysing the situation when the double standards are used are pre-agreed rules are violated by those wishing to maximize their profits, career advancements, and well-being. While many researchers criticize the uncritical treatment of bibliometrics and developments in "political economy of meta-data" offered by Scopus and Web of Science databases, they cannot offer a better alternative. Turning our backs on the world-renowned databases and creating our own local databases and (black) lists would sooner or later lead to a situation in which a small academic mafia will control all power. The mafia will make decisions on which articles (and which journals) are accepted and which are not, and who is going to get a bigger slice (grants, funding and promotion) of the academic pie. This would clearly be unethical and non-democratic, but this is also the path academic communities of the Central and Eastern European countries are stepping upon. The situation is very alarming, and measures should be taken before it is too late, and the science and research are privatized and corrupted in the hands of the ruthless small groups of academics.

The analysis of previous researches and publications. Beall's "list of potential, possible, or probable predatory scholarly open-access journals" appeared in 2012 as his reaction to the Open Access (OA) publishing model that emerged as the alternative to the large publishing companies that controlled the vast share of the academic publishing market. OA model lets the authors to pay for the publication of their papers once they are peer-reviewed and accepted for publication (so-called "author pays principle"). However, despite all its obvious advantages, Beall disliked the OA and virtually blamed all OA journals for being "predatory" (i.e. attracting researchers and offering them to publish their papers quickly for money without proper peer review) [6; 7]. In the same time, he never even touched the subject of non-OA journals, especially the journals published by the large publishing companies (even though some of them were also found to conduct quite "predatory" practices) [8]. Thence, Beall's logic and his approach were and are still criticized by many scientists - one can see that it is burdened by many controversies, highly politicized, probably sponsored by business companies and therefore cannot be taken seriously. One would probably agree that charging a fee does not make a journal "predatory" many reputable journals published by the reputable publishing houses charge publication fees based on their 
"author pays principle" or offering the authors to grant open access to their published papers (therefore helping to increase downloading and citations) in exchange for hefty sums. Additionally, one has to remember that Beall constantly updated his list by adding and removing the journals and publishers from the list without keeping any time logs. If one accepts the fact that once the journal is added to the "Beall's List" for some period of time, all publications in this journal should be considered "predatory", the implications might be that everyone and his mother is publishing in predatory journals. This would be true in the case of the Czech Republic where top scientists from the Czech Academy of Sciences and the Charles University in Prague, just to name a few, were and are publishing in the Hindawi and MDPI journals that were once on "Beall's List" [9; 10]. Moreover, they are publishing in PLOS ONE, the pioneer of OA movement that was often condemned by Beall who called it a failure [11].

Long story short, "Beall's List" did not survive for long. In January 2017, Jeffrey Beall shut down his blog, removed his "list" from the Internet and stopped all his online activities altogether (even though he still attends various conferences on "predatory" publishing, most often at the former USSR countries such as Kazakhstan or Russian Federation, as a honoured guest and a "famous professor"). However, academic publishing became even more difficult without the "Beall's List" - it was troublesome and hardly trustworthy when it still existed but there is nothing to replace it once it is gone [12].

Basic materials. The issue of "predatory" journals seem to bother Czech academics more than anyone in the world. The researchers from this small nation seem to be very preoccupied about it. According to the estimates made by Věda žije ("Science Lives"), a public initiative, between 2009 and 2013 many Czech universities made around \$2 million from their researchers their papers and monographs in "predatory" publishing outlets [13]. Publishing diploma theses as research monographs with Lambert Academic Publishing, allegedly a "predatory" and "vanity press" outlet, was very popular and some highly-ranked university managers even encouraged their students to do so [14].

Until recently, Czech social scientists did not bother much about publishing in English in top academic journals. Most of them published their research in Czech in local peer-reviewed journals and proceedings. Locally-published books and monographs were considered to be of higher importance for boosting careers and acquiring academic position and degrees. They still are in some fields of the Czech science - for instance Czech sociologists publish their monographs at Sociologické nakladatelství (SLON), a publishing house that is registered in an apartment in a residential building at the outskirts of Prague and features long-deceased academics in its Scientific Board [15].

This situation changed when the focus shifted on publishing in journals listed in Thomson Reuters ISI Web of Knowledge database. In those days, all academic journals listed in this database were considered "prestigious peer-reviewed journals" without distinguishing between their rankings.

In 2013, the situation fundamentally changed when the Research, Development and Innovation Council of the Czech Republic adapted its Methodology of remuneration for academic publications in the Czech Republic for the years of 2013-2016 [16]. In accordance with the new methodology, the remuneration was conducted based on the points assigned to each publication based on its weight and significance. Publications with an IF and indexed in ISI Web of Knowledge and publications indexed in Scopus gained similar status. For the period of 2013-2016, the formula for attributing the points to the academic publications was set as follows:

$$
\mathrm{Jimp} / \mathrm{sc}=10+295 \times \text { Factor }
$$

where Factor is the adjusted IF for ISI Web of Knowledge journals, and the SJR for Scopus-indexed journals.

The methodology is presented in Table 1 that follows. It becomes apparent that the value of Scopus-indexed publications and ISI Web of Knowledge publications has levelled and yields the same output. Moreover, it is also apparent that the value of book chapters and research monographs declined considerably. 
Table 1 - Evaluation of the research publications in the Czech Republic (2013-2016) ([16])

\begin{tabular}{|c|c|c|c|}
\hline \multicolumn{3}{|c|}{ Type of research output } & Points \\
\hline Jimp & \multicolumn{2}{|c|}{ Journal with IF indexed in ISI Web of Knowledge } & $10-305$ \\
\hline JSC & \multicolumn{2}{|l|}{ Journal index in Scopus } & $10-305$ \\
\hline \multirow[t]{3}{*}{ Jnonimp } & \multirow[t]{3}{*}{ Journal indexed in ERIH } & INT1 & $12-30$ \\
\hline & & INT2 & $11-20$ \\
\hline & & NAT & 10 \\
\hline Jrec & \multicolumn{2}{|l|}{ Czech peer-reviewed journal } & $0-4$ \\
\hline$B$ & \multicolumn{2}{|l|}{ Research monograph } & $4-120$ \\
\hline $\mathrm{D}$ & \multicolumn{2}{|l|}{ Book chapter } & $8-60$ \\
\hline
\end{tabular}

In accordance with the methodology above, Czech academics submit a list of their publications to their Departments or Institutes. The publications are then evaluated at the Department level, then the whole Faculty level, and then submitted via an electronic system to the Central Library (e.g. in the case of the Charles University in Prague) level. The library then compiles the lists and submits them to the Czech Research Evaluation (RIV) submission system.

Each publication is assigned a certain number of points (from 10 to 305). The monetary value of the single point in 2014 was set at about CZK 4.000 (about $€ 150$ ) with the decline in subsequent years to CZK 3.000 ( $€ 110$ ) and lower. Based on these criteria, the monetary reward is calculation for each Czech institution (the money is divided proportionally between the Czech institutions and the foreign co-authors are not rewarded). The money for each publication output goes to the respective institution (University or research institute), where about one half of it is kept at the Rectorate or higher management level for the institutional needs, and the rest goes to the department or the institute where the respective author originates from. The departments and institutes take the money and pay the reward to the authors (quarterly or annually) in accordance with their internal guidelines. In most of the cases, a remuneration for the Scopus-indexed publication would vary between CZK $3.000(€ 110)$ and CZK 10.000 (€370), while a paper in a journal indexed on Web of Science yielded from CZK 10.000 (€370) to CZK 20.000-30.000 (€750-1.100).

Hence, the rules are that all publications listed in Scopus and Web of Science databases are rewarded. Moreover, the system of control (which publication gets into the system) is strict and has at least 3 levels of internal check and thorough control. In addition, it is the university or the research institute that mostly profits from the publications, since the authors receive just a small margin of the money allocated based on the points attributed to their publications. This approach was criticized by some Czech researchers, but it remained in place for several years without any amendments [17].

One possible explanation might be that the academic job market in the Czech Republic is rigid and the number of posts is limited. Apart from that, a job in the academia does not earn much. In the recent Inomics academic job market report [18] the annual salary of a lecturer in the Czech Republic is reported to be below $\$ 15.000$ (the same as in Albania or Ukraine). Just for the comparison: lecturers in the United Kingdom receive $\$ 47.000$ a year, while their counterparts in Australia and the United State receive $\$ 69.000$ and $\$ 76.000$ respectively. In the same time, the Czech Republic is one of the few countries where the government (at least until recently) payed universities and research institutions for the research output produced by their employees.

A case study: Stöckelová controversy. The best way of demonstrating how some academics are attempting to change the rules of the game during the game for their own benefit, profit and career advancement, is to use the example of the so-called "Stöckelová controversy" from the Czech Republic.

Having finished her Master studies in the field of Sociology at the Charles University in Prague in 2001 and her doctoral studies at the same university, Tereza Stöckelová became an assistant professor/lecturer at the Faculty of Humanities at Charles University in Prague. She has also joined the Institute of Sociology of the Czech Academy of Sciences as a researcher and soon became an Editor-in-Chief of the English 
edition of the Sociologický časopis (Czech Sociological Review)- an academic journal indexed by Scopus and Web of Science databases and published by the Institute of Sociology of the Czech Academy of Sciences. Stöckelová considers herself to be something like a Czech watchdog of science and academia and she likes to blog about it with her friends: The current globally shared obsession with "exact" bibliometric measurements of research productivity and impact is a source from which predatory/parasitic publishing spawns, rather than a remedy for it [19].

During her 20-year long academic career at multiple Czech research institutions, Stöckelová managed to write and publish just 10 papers in the journals indexed in Scopus and Web of Science (about 1 paper each 2 years), including 2 papers in the Czech Sociological Review, a journal she edited and published herself. However, in spite of her mediocre academic output, she was able to get a promotion to an associate professor at the Faculty of Social Sciences at Charles University in Prague in 2016. Her promotion was mostly based on her book published entitled "Nebezpečné známosti" (Dangerous Liaisons) which had a subtitle "about the relationship between social sciences and society" [20]. Stöckelová's "Dangerous Liasons" did not reach the popularity of "Les Liaisons Dangereuses" (a 1782 book by Pierre Choderlos de Laclos popularized in the modern culture by the 1999 film "Cruel Intentions" starring Sarah Michelle Gellar, Ryan Phillippe, Selma Blair, and Reese Witherspoon) and many Czech sociologists consider Stöckelová' opus magnum to be pseudo-scientific nonsense.

Stöckelová's book version of modern-day Marquise de Merteuil and the Vicomte de Valmont (two manipulators who use seduction and intrigues to socially control and exploit the others, most probably like Stöckelová herself like to do) was published in 2012 by the (already described above) the SLON publishing house which lists her friends alongside with the deceased Professor Miloslav Petrusek as the members of the Editorial Committee. Although SLON publishes numerous research monographs in the field of sociology that are used by academics like Stöckelová for doing habilitations (being promoted to an associate professor) in the Czech academic system, it operates from an apartment building on the outskirts of Prague (a criterion typically used by Jeffrey Beall (together with using the names of non-existent or deceased academics as the members of the editorial boards) for adding such a business to his famous list of "possible and probable predatory publishers") [15].

Apart from her rather poor academic performance, Stöckelová is very active in politics being a zealot anarchist and a spokeswoman of ProAlt, a "populistic, left-wing, extremist, anarchist, and possibly radical Communist" movement according to the Ministry of the Interior of the Czech Republic (2011) [21].

Despite Stöckelová's two jobs at the Czech Academy of Sciences and the Charles University in Prague and her modest publication output, she seems to have plenty of time for protesting against anything and everyone and writing and maintaining a blog on academic publishing called DeRIVace [19]. Here is what she and her colleagues say about academic publishing in their blog: We must not forget that the motivation of the two databases [Scopus and Web of Science], which are owned by private corporations and equity funds, is to make a profit rather than measure quality (which seems a contradictory expression - can quality in any way be measured?). What's more, the profit-driven character of Web of Science is likely to deepen under the new ownership of Onex and Baring Asia.

Science is subjected to severe bloodletting... by the established publishers who act as bloodsuckers, this time more amorphous and truly gigantic, who leach off public budgets for science (e.g. libraries' subscription costs, scientists' salaries, research expenses) and often the non-paid labour of authors, editors, and reviewers [19].

However, while being a zealot fighter against "predatory publishing" and a critic of Scopus and Web of Science [22], Stöckelová does not hesitate to publish her 2-page editorials and "open letters" as articles in the journal she edits bypassing the peer review and using it for her own political agenda. She knows that her "papers" will be indexed in Web of Science database and thus read and appreciated by the academic community. Similar to Jeffrey Beall who focused too much on the political agenda in his pursuit 
of "predatory journals", Stöckelová tend to forget that such debates should be carried out on social media, not in academic, peer-reviewed papers. For example, in her recent paper written and published by herself in the journals she also edits (obviously without any peer review), she criticizes European Sociological Association for setting up the conference fees for their Prague conference too high or charging an extra $€ 40$ for the conference dinner in a luxury restaurant at Vltava River [23].

Of course, there are more stories like that related to the Czech Sociological Review and SLON publishing house as well as people who are lurking around it using the journal's prestige thanks to its indexation in Scopus and WoS. Careers are built, and research grants are earned while the same very people use the agenda of "predatory publishing" in order to draw attention from their own unethical academic practices. It is interesting to learn that the people gathered around the Czech Sociological Review (a journal that probably also deserves to be added to the "Beall's List" for the unethical practices of its editors like Stöckelová [24]) were the ones who invited Jeffrey Beall to Prague in June 2016 for a conference on "predatory publishing". The darkest place is always under the candlestick.

All in all, "Stöckelová's controversy" is a clear example of parasitism and wasting taxpayers' money. It becomes clear that many Czech academics are unlikely to survive outside the walls of their universities and research institutions since they have a poor command of English, lack any international experience and thus are unemployable outside the Czech academia. This is the reason why many people employed in the Czech research institutions are prepared to go to great length to hold on to their jobs. Intrigues, false accusations, involvement of the corrupt mass media - all these become the tools of getting rid of the competition and secure the hefty portion of the academic pie in the Czech on-going "predatory" journals' storm in a teacup.

\section{Reputation in "danger"}

The most recent example of the academic wars (journalism studies against international relations this time) over the small academic pie in the Czech Republic that once again used the "Beall's List" (longforgotten and non-existend for a year now) as its only possible aid (in the absence of the more solid arguments), was the election of Dr. Alice Němcová Tejkalová as the new Dean of the Faculty of Social Sciences, Charles University. Dr. Němcová Tejkalová had many rivals who also dreamed about the Dean's position and who initiated yet another blog (Czech academic seem to love blogs and apparently spend more time keeping them than producing meaningful academic output in the form of papers in the journals indexed in Scopus and Web of Science) that called to the academic community askin to help upholding academic standards at the Charles University [25].

The blog was created by Dr. Anna Durnová, a fellow at the Vienna's Institute for Advanced Studies and the Director of the Board of the Institute of International Relations in Prague (which also lists many academics from the Faculty of Social Sciences). Dr. Durnová and her two colleagues managed to collect online signatures of about 300 people, mostly students and academics with a mediocre research output (around 10 published papers in the journals indexed in Scopus and Web of Science), and challenged Professor Zima, the Rector of the Charles University, asking him not to appoint Dr. Němcová Tejkalová. The whole thing became the new "Durnová controversy".

Professor Zima released a statement in which he claimed that the only criterion for academic publishing recognized (and approved) by the Charles University (he represented as a Rector) was whether the journal in question was indexed in Scopus and Web of Science with the "Beall's List" being irrelevant in this case. He also stated: "I should point out that Beall's List is an indicative aid and the mere fact that someone has published a paper in a journal listed in it is not automatic evidence of unethical conduct" [26].

In spite of this clear position, Durnová and her colleagues are still rocking the boat and igniting the new academic witch hunt in the Czech Republic. Somehow, they persuaded Mr. Jack Grove who holds a BA in English from the University of Bristol to report on the Czech academic war in the manner such as "scholars claim dean-elect is unfit for office after publishing articles in journals found on Jeffrey Beall's 
blacklist" in Times Higher Education [27]. Mr. Grove is blindly picking up Durnová's arguments that created the new category of "suspicious" journals: i) "journals not on Beall's list that, nonetheless, show clear signs of being junk journals", or ii) "fraudulent journals" that "failed to meet basic scholarly standards". If these two new categories were actually used, the majority of academic journals in the Czech Republic (as well as everywhere else in the world), would be labelled as "fraudulent" and "junk".

It becomes apparent that the whole debate (as well as Durnová's and Grove's argumentation) is meaningless and only shows that we should rely upon the journal's indexation in Scopus and Web of Science regardless of any blogs and lists, otherwise we would face more academic witch hunts such as those initiated by Jeffrey Beall. The creation of more "journal black lists" would enable small groups of academics to control job promotions within the research instructions and universities and influence the division of state funding envisaged for supporting research and innovations.

Conclusions and discussions. There are many questions left unanswered in the debate about "predatory" journals in academic publishing in the Czech Republic and worldwide. For instance, no one has ever given a clear recommendation on what to do about the journals suspected of predatory practices that are indexed in reputable citation databases such as Scopus or the Web of Science. Should we publish in them anyway or should we search for some other lists and publishing ethics committees' guidelines now that Beall is gone? And if so, who will appoint these committees or who will decide which journals are good and which are bad?

The case of Czech academic debate over the "predatory journals" shows many interesting implications: First, it is peculiar that the people who are fighting against "predatory" publishing are publishing in the very same "predatory" outlets themselves (the case of the top representatives of the Czech most respectable research and educational institutions). Second, the case of Tereza Stöckelová shows how dangerous it is when political activism mingles with research and academia. The result of this dangerous mixture might be that logic and rules can be removed in the pursuit of the political agenda. Third, it is important to understand and to accept that in any democratic society the rules of the game cannot be changed while the game is played. There are established rules of the academic publishing (the standards of recognizing the papers in journals indexed in Scopus and Web of Science) and it is very wrong to come in mid-game and start inventing the new "blacklists" of "fraudulent" and "junk" journals and setting up the new rules. One can only ask: "Who will cast the first stone?".

\section{Acknowledgement}

The authors would like to thank two anonymous reviewers, the journal editor and the technical editors for valuable conceptual and editorial suggestions on earlier drafts of the article.

1. Strielkowski, W. (2017). Will the rise of Sci-Hub pave the road for the subscription-based access to publishing databases? Information Development, 33(5), 540-542. DOI: 10.1177/0266666917728674.

2. Brembs, B., Button, K., \& Munfaro, M. (2013). Deep impact: unintended consequences of journal rank. Frontiers in Human Neuroscience, 7:291. DOI: 10.3389/fnhum.2013.00291.

3. Grancay, M., Vveinhardt, J., \& Sumilo, E. (2017). Publish or perish: how Central and Eastern European economists have dealt with the ever-increasing academic publishing requirements 2000-2015. Scientometrics, 111(3), 1813-1837. DOI: 10.1007/s11192-017-2332-z.

4. Beall, J. (2012). Predatory publishers are corrupting open access. Nature, 489 (7415), 179. DOI: 10.1038/489179a.

5. Strielkowski, W., Gryshova, I., \& Shcherbata, M. (2017). Predatory publishing and Beall's list: lessons for the countries adapting novel research evaluation criteria. Science and Education, 8, 39-43. DOI: 10.24195/2414-4665-2017-8-5.

6. Beall, J. (2012). Predatory publishers are corrupting open access. Nature, 489(7415), 179. DOI: 10.1038/489179a.

7. Beall, J. (2015). Predatory journals and the breakdown of research cultures. Information Development, 31(5), 473-476. DOI: $10.1177 / 0266666915601421$.

8. Hutson, S. (2009). Publications of fake journals raises ethnical questions. Nature Medicine, 15, 598. DOI: 10.1038/nm0609-598a.

9. Kalousova, M., Dusilova-Sulkova, S., Zakiyanov, O., Kostirova, M., Safranek, R., Tesar, V., \& Zima, T. (2015). Vitamin D Binding Protein Is Not Involved in Vitamin D Deficiency in Patients with Chronic Kidney Disease. BioMed Research International, article ID 492365, 1-8. DOI: 10.1155/2015/492365. 
10. Retzer, K., Lacek, J., Skokan, R., del Genio, C. I., Vosolsobě, S., Laňková, M., \& et al. (2017). Evolutionary Conserved Cysteines Function as cis-Acting Regulators of Arabidopsis PIN-FORMED 2 Distribution. International Journal of Molecular Sciences, 18(11), 2274. DOI: 10.3390/jims18112274.

11. Beall, J. (2017). What I learned from predatory publishers, Biochemia medica: Biochemia Medica, 27(2), 273-278. DOI: 10.11613/BM.2017.029

12. Strielkowski, W. (2017). Bell's List is missed. Nature, 544, 416. DOI: 10.1038/544416b.

13. Věda žije. Vysoké školy čerpaly prostředky z MŠMT za diplomové práce přetištěné jako odborné knihy [Universities received money from the Ministry of Education, Youth and Sport for diploma theses printed as scientific monographs] (2016) vedazije.cz. Retrieved from http://vedazije.cz/node/5101 [in Czech].

14. Novotny, J. (2015). Predátorská vydavatelství útočí. Vysávaji český rozpočet na vědu [Predatory publishers are attacking. They drain the Czech budget for science]. euro.cz. Retrieved from https://www.euro.cz/archiv/predatorska-vydavatelstvi-utocivysavaji-cesky-rozpocet-na-vedu-1255068 [in Czech]

15. SLON (2017). SLON: Sociologické nakladatelství [Sociological publishing]. slon-knihy.cz. Retrieved from www.slonknihy.cz [in Czech].

16. Research, Development and Innovation Council of the Czech Republic (2013). Methodology of remuneration for academic publications in the Czech Republic for the years of 2013-2016. vyzkum.cz. Retrieved from http://www.vyzkum.cz/FrontClanek.aspx?idsekce=685899.

17. Linková, M., \& Stöckelová, T. (2012). Public accountability and the politicization of science: The peculiar journey of Czech research assessment. Science and Public Policy, 39(5), 618-629. DOI: 10.1093/scipol/scs039.

18. INOMICS (2014). Job market survey. 2014. inomics. com. Retrieved from www.inomics.com.2014-job-market-survey.

19. Brož, L., Stöckelová, T., Vostal (2017). Predators and bloodsuckers in academic publishing. derivace.wordpress.com. Retrieved from https://derivace.wordpress.com/.

20. Stöckelová, T. (2012). Nebezpečné známosti. O vztahu sociálních věd a společnosti [Dangerous acquaintances. About the relationship between social sciences and society]. Praha: Sociologické nakladatelství SLON [in Czech].

21. Ministry of the Interior of the Czech Republic (2011). mvcr.cz. Extremism: overall situaton report. Retrieved from http://www.mvcr.cz/soubor/zprava-extremismus-3q-pdf.aspx.

22. Stöckelová, T., Vostal, F. (2017). Academic stratospheres-cum-underworlds: when highs and lows of publication cultures meet. Aslib Journal of Information Management, 69(5), 516-528. DOI: 10.1108/AJIM-01-2017-0013.

23. Stöckelová, T. (2016). Sociological imagination for Future ESA Conferences. Sociologicky casopis-Czech Sociological Review, 52(3), 403-404.

24. Beall, J. (2015). Predatory journals and the breakdown of research cultures. Information Development, 31(5), 473-476. DOI: $10.1177 / 0266666915601421$.

25. Durnová, A., Komm, M., \& Trtíková Vojtková, M. (2017). Reputation in danger: upholding academic standards at Charles University. reputationindanger.com. Retrieved from https://reputationindanger.com.

26. Zima, T. (2017). Rector's Zima reaction to the open letter. cuni.cz. Retrieved from https://cuni.cz/UK-8704.html.

27. Grove, J. (2017). Czech University urged to bar new dean over "junk journal" papers. timeshighereducation.com. Retrieved from https://www.timeshighereducation.com/news/czech-university-urged-bar-new-dean-over-junk-journal-papers\#survey-answer.

A. Молчанова, канд. наук, Інститут перспективних напрямків і технологій, Російський державний соціальний університет (м. Москва, Російська Федерація);

Н. Чунихина, канд. наук, кафредра бізнес-інформатики та математики, Тюменський індустріальний університет (м. Тюмень, Російська Федерація);

B. Стрієлковські, PhD, Центр досліджень сайентометріi, професор Празької бізнес-школи (м. Прага, Чехія); Запрошений вчений, Каліфорнійський університет, Берклі (м. Берклі, США)

Інновації та академічні видання: хто кине перший камінь?

Академічна публікаційна активність завжди була відкрита для різних інновацій. Публікації в престижних академічних журналах здійснюють значний вплив на інституційні рейтинги та допомагають дослідникам отримати грантове фінансування. Але питання про те, «де» публікуватися, стало важливіше за питання про те, «що» публікувати.

Чеська Республіка - одна з країн, які, схоже, особливо одержимі проблемою «хижих» журналів, які породили бурю в склянці води. Усі в Чеській Республіці (включаючи вище керівництво провідних університетів країни і Академії наук) видавалися і продовжують видаватися в журналах, які колись вважалися «хижацькими» відповідно до списку, складеного Джефрфрі Біллом (наприклад журнали видавництв MDPI або Hindawi). Багато чеських вчені отримують підвищення на основі публікаиії своїх монографрій в маловідомих видавництвах, розташованих в багатоквартирних будинках, або публікацій статей в журналах, які вони редагують, в обхід рецензії та експертної оцінки (знаменитий «суперечка Терези Штоккеловой»).

За деякими оцінками, у період між 2009 і 2013 роками чеські університети заробили близько 2 мільйонів доларів завдяки публікації статей і монографрій в "хижацьких» видавництвах. Існування "хижацьких» журналів дозволило менш продуктивним чеським вченим (як правило, у галузі суспільних наук) поставити під сумнів систему загальносвітових академічних показників світу, таких, як Scopus i Web of Science. Однак відхід від всесвітньо відомих баз даних і створення 
національних стандартів публікацій, безсумнівно, дозволять невеликим групам місцевих вчених контролювати систему академічних рейтингів та наукової продуктивності. Тільки такі наукові бази даних, як Scopus i Web of Science, пропонують об'єктивну та неупереджену систему оцінки на основі міжнародних критеріїв і дозволяють об'єктивно оцінювати академічну продуктивність.

Ключові слова: інновації, академічні публікації, хижацькі журнали, суперечка Штоккеловой, суперечка Дурновой, рецензування, Scopus, Web of Science.

А. Молчанова, канд. наук, Институт перспективных направлений и технологий, Российский государственный социальный университет (г. Москва, Российская Федерация);

H. Чунихина, канд. наук, кафедра бизнес-информатики и математики, Тюменский индустриальный университет (г. фвТюмень, Российская Федерация);

B. Стриелковски, PhD, Центр исследований сайентометрии, профессор Пражской бизнес-школы (г. Прага, Чехия); Приглашенный ученый, Калифорнийский университет, Беркли (г. Беркли, США)

Инновации и академические издания: кто бросит первый камень?

Академическая публикационная активность всегда была открыта различным инновациям. Публикации в престижных академических журналах оказывают значительное влияние на институциональные рейтинги и помогают исследователям получить грантовое финансирование. Тем не менее вопрос о том, «дде» публиковаться, стал важнее вопроса о том, «что» публиковать.

Чешская Республика - одна из стран, которые, похоже, особенно одержимы проблемой «хищных» журналов, породивших бурю в стакане воды. Все в Чешской Республике (включая высшее руководство ведущих университетов страны и Академии наук) издавались и продолжают издаваться в журналах, которые когда-то считались «хищническими» в соответствии со списком, составленным Джефрфри Биллом (например журналы издательств MDPI или Hindawi). Многие чешские ученые получают повышение на основе публикации своих монографрий в малоизвестных издательствах, расположенных в многоквартирных домах, или публикаций статей в журналах, которые они редактируют, в обход рецензии и экспертной оценки (знаменитьй «спор Терезы Штоккеловой»).

По некоторым оценкам, в период между 2009 и 2013 годами чешские университеты заработали около 2 миллионов долларов благодаря публикации статей и монографиий в «хищнических» издательствах. Существование "хищнических» журналов позволило менее продуктивным чешским ученым (как правило в области общественных наук) подвергнуть сомнению систему общемировых академических показателей мира, таких как Scopus u Web of Science. Однако отход от всемирно известных баз данных и создание национальных стандартов публикаций, несомненно, позволят небольшим группам местных ученых контролировать систему академических рейтингов и научной продуктивности. Только такие научные базы данных как Scopus u Web of Science предлагают объективную и беспристрастную систему оценки на основе международных критериев и позволяют объективно оценивать академическую производительность.

Ключевые слова: инновации, академические публикации, хищнические журналы, спор Штоккеловой, спор Дурновой, рецензирование, Scopus, Web of Science.

Отримано 15.04.2017 p. 